\title{
Carpathian-Balkan Geological Association
}

\section{http://www.rfg.bg.ac.yu/KBGA}

Carpathian-Balkan Geological Association (CBGA), according to its Statute, "is non-governmental, international, scientific, non-political and non-profit making union of geoscientists working in the Carpathian-Balkan realm" and surrounding areas. The membership of CBGA is collective and it is "open to geoscientists of all countries of the Carpathian-Balkan" and neighboring countries. Application of collective membership "should be submitted by competent scientific bodies".

\section{Aims}

According to CBGA Statute "The aim of CBGA is to promote and encourage joint fundamental and applied geological research, as well as training and specialization in the Carpathian-Balkan realm". This concerns virtually all branches of the geological sciences (including geophysics), their environmental implications, and other related disciplines. In order to accomplish that aim CBGA: (1) organizes a Congress every four years by one or several collective members; (2) establish Standing Commissions and organizes their work on projects; (3) starts discussions and adjusts opinions concerning geological nomenclature, terminology, methodology and other scientific problems; (4) issues different kind of publications (congress proceedings, maps, monographs and other scientific products).

\section{History}

The Association was initially founded as the "Carpathian Geological Association" in 1922 at the XIII Session of the IGC in Bruxelles. The creation of this association was due to the personal initiative of R. Kettner (Czechoslovakia), J. Nowak (Poland), G. Munteanu Murgoci (Romania) and V. Petkovic (Yugoslavia). The main purpose of CGA was to establish closer relations between geologists on the study of the Carpathian geology. It was agreed that every year there would be meetings in member countries to discuss scientific questions and to visit the localities of geological interest in the host country.

The first congress CGA was held in Lvov (then in Poland) in 1925, the second in Bucharest in 1927 and third in Prague in 1931. The successful work of the Association was cancelled before the Second World War.

After the war, on the suggestion of Czechoslovak and Romanian geologists at XX IGC in Mexico (1956), the work of the Association

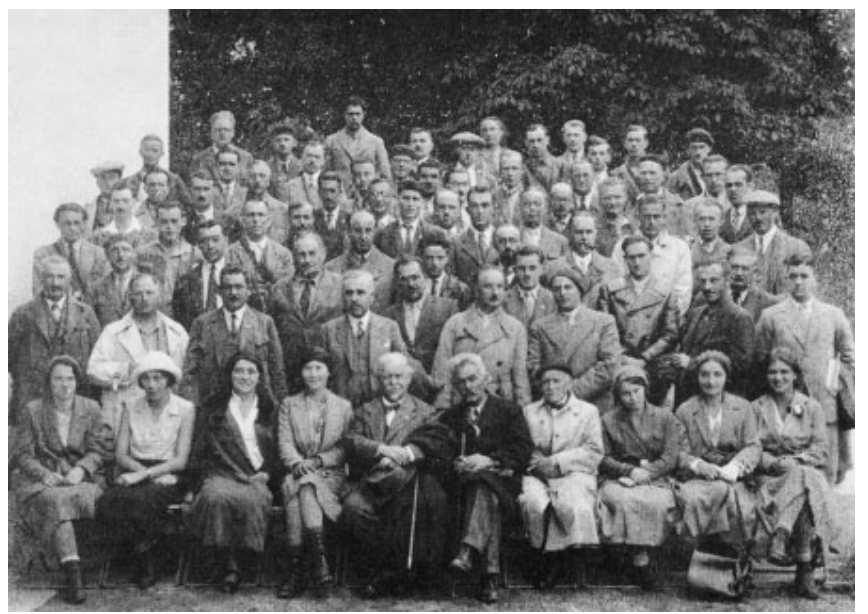

Participants of the 3rd Congress in Czechoslovakia 1931. was renewed in the enlarged form. Then Bulgaria, Hungary and USSR (Ukraine) joined the "Carpathian-Balkan Geological Association". Later members of the CBGA became geologists from Albania, Austria, Czechia, Greece, Macedonia and Slovenia. With the disintegration of USSR, Czechoslovakia and Yugoslavia geologists from Ukraine, Slovakia and Serbia remained in the CBGA. Association has twelve members today from Mid- and SouthEastern Europe.

The new cycle of CBGA Congresses started with the IV in Kiev (1958) and continued with $\mathrm{V}$ in

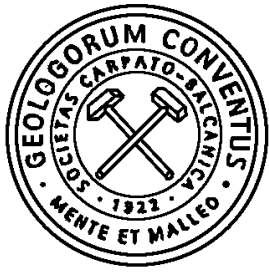

Bucharest (1961), VI in Warsaw and Krakow (1963), VII in Sofia (1965), VIII in Belgrade (1967), IX in Budapest (1969), X in Bratislava (1973), XI in Kiev (1977), XII in Bucharest (1981), XIII in Krakow (1985), XIV in Sofia (1989), XV in Athens (1995), XVI in Vienna (1998) and XVII in Bratislava (2002). The next one, XVIII will be held in Belgrade in 2006.

On the congresses the geologists from the host country present the state of geological knowledge of their territory. For that occasion they usually prepare one or more synthetic papers, tens of special articles, geological maps and guides for field trips. Geologists from other collective members of CBGA and guests from nonmember countries also report their new research results. Special attention is given to the field trips.

\section{Organizing structures}

Two permanent directing bodies of CBGA are the Board and the Council.

The Board consists of the President, the Vice President, Secretary General and Past President of the CBGA. The Board is the governing body of the Association between two congresses.

The Council consists of one representative from each collective member (respective National Committee). "The Council has to supervise all activities of CBGA, accept, postpone or reject proposals and to adopt resolutions ... The Council meets at least once in two years ... The Council meetings are charged by representative of the host country".

National Committees of CBGA govern the work of geologists in the collective member countries.

In the organizing structure of CBGA, the Standing Commissions have very important places. After the renewal of its work in 1956, following the example of IGC (later IUGS), the number of Commissions was organized in CBGA (for Tectonics, Mineralogy, Geochemistry, Magmatism, Metamorphism, Stratigraphy, Sedimentology, Hydrogeology, Engineering Geology, Ore Deposits, Geological Maps and Geophysics). Every collective member had its representative in them. In their Programme Commissions had concrete aims and projects. During the five decades there were many very important projects. However, in recent times it was observed 
that Commissions became cumbersome, inert and almost disinterested in work. The problem of the financing of their work also occurred. At the moment, the process of amending the Statute is taking place. Standing Commissions need to be changed into dynamic Working Groups, composed of the smaller number of interested members. Some of them already work this way as an experiment.

\section{Activities and perspectives}

All that is done within CBGA is entirely scientific activity in all fields of geology. All the previous Congresses saw that the geology of the $\mathrm{CB}$ region had successful development and that it followed modern trends of this science. In perspective it is expected that it would continue to be that way. Aside from that, the future Working Groups would continue the praxis of solving geological problems in the $\mathrm{CB}$ region and surrounding countries through various thematical and regional geologic projects.

\section{Publications and achievements}

Two groups of publications are published in the CBGA: (a) congress and symposia proceedings and (b) results of collective work of Standing Commissions.

After the finished congresses and symposiums there are published papers, abstracts and guides for field trips. Until now in that way 65 books of Congress papers and tens of field trip guides have been published. Recently along with the classical press there are electronic editions too.

As a result of the work of the Standing Commissions the geological maps, explanation books, monographs, tables with comparative nomenclature are published. It is sufficient to list just a few examples. The Commissions for Tectonics, Petrography, Metamorphism, Sedimentology, Geochronology, Hydrogeology and Engineering Geology compiled and printed important generalized maps of the region on the scale $1: 1000.000$. Aside from that they published also several thematic monographs. Geophysical Commission contributed considerably to the knowledge of the Earth crust and upper mantle of the region.

\section{Relationship with IUGS}

The Carpathian-Balkan Geological Association is affiliated to the International Union of Geological Sciences as a regional organization. That way this Association directly linked to the activities of all members of the IUGS. Therefore different bodies of IUGS hold their meeting and symposia along with other international organizations (for example IGCP UNESCO), at the CBGA Congresses.

\section{Officers}

Today the CBGA is governed from Belgrade by the Board with the following members: Prof. Dr Aleksandar Grubiç President, Acad. Stevan Karamata, Vice President, Prof. Dr Marko Ercegovac, Secretary General and Prof. Dr Jozef Vozar, Past President (Slovakia). The Organizing Committee has already been working hard on the organization of the XVIII Congress of CBGA to be held in September 2006

Prof. Dr. Aleksandar Grubic

President, Carpathian Balkan Geological Association

Faculty of Mining and Geology

Kamenicka 6

11001 Beograd

SERBIA AND MONTENEGRO

Tel: $+381-11-26-32-166$

Fax: +381-11-26-31-137

E-mail:18.cbga@scentar.co.yu

\section{Episodes is your window to the world. Subscribe today!}

\section{Episodes}

\section{Subscription Order}

Name

(please print)

Address

\begin{tabular}{ll} 
City $\_$State/Prov. \\
Country $\_$Zip/Postal Code \\
\hline
\end{tabular}

Please begin my subscription:

$\begin{array}{llll}\text { March } & \text { June } & \text { Sept. } & \text { Dec. } \\ \text { Year } & \text { Year } & \text { Year } & \end{array}$

To start your subscription, fill in this form and mail to:

Episodes

P.O. Box 823

26 Baiwanzhuang Rd.,

Beijing 100037, China

Tel: +86-10-6832 0827; +86-10-68329084

Fax: +86-10-6832 8928

E-mail:episodes88@yahoo.com
Payment may be made by:

- Checks (US \$ only) made payable to Episodes

- $\square$ Diners $\square$ JCB $\square$ Visa

$\square$ American Express $\square$ Mastercard

Please quote account number, expiry date and signature.

Account\#

Expiry date

Signature

Annual subscription rates: US\$24 